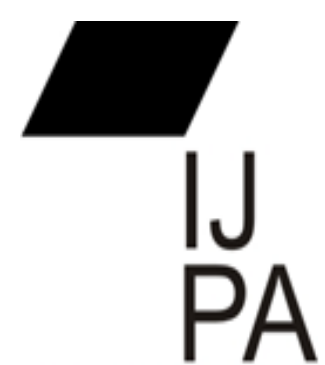

ISSN $2460-0369$

\title{
PENERAPAN PELAYANAN PUBLIK BERBASIS TEKNOLOGI INFORMASI MELALUI WEB DOMAIN DI KOTA SURAKARTA
}

\author{
Bambang Irawan, Adi Saputro
}

\section{Program Studi Administrasi Publik \\ Universitas 17 Agustus 1945 Jakarta - Indonesia \\ Bambang.irawan@uta45jakarta.ac.id}

\begin{abstract}
Today's service is a fundamental need for every human being. Therefore, the government must provide effective and efficient public services for the citizen to fulfill all their interests. The government strives to implement information technology-based services to achieve excellent services. The purpose of this research is to determine the success of the implementation of information technology-based governance, especially in Surakarta City. This type of research is qualitative with a case study design. The implementation of information technology-based governance in the city of Surakarta can be said to be quite successful seen from the provision of services and responses to the citizen.
\end{abstract}

Keywords: Services, technology-based governance, implementation

\begin{abstract}
Abstrak, Pelayanan saat ini merupakan kebutuhan yang fundamental bagi setiap manusia. Maka dari itu pemerintah harus menyelenggarakan pelayanan publik yang efektif dan efisien bagi masyarakat agar terpenuhi segala kepentingannya. Pemerintah mengupayakan untuk menerapkan pelayanan berbasis teknologi informasi guna tercapainya pelayanan yang prima. Tujuan penelitian ini untuk mengetahui keberhasilan pelaksanaan pemerintahan berbasis teknologi informasi khususnya di Kota Surakarta. Jenis penelitian ini adalah kualitatif dengan rancangan studi kasus. Pelaksanaan penyelenggaraan pemerintahan berbasis teknologi informasi di Kota Surakarta dapat dikatakan cukup berhasil dilihat dari penyediaan layanan dan tanggapan kepada masyarakat.
\end{abstract}

Kata Kunci : Pelayanan, teknologi informasi, pelaksanaan 


\section{PENDAHULUAN}

Penyelenggaraan pelayanan publik sudah menjadi kewajiban pemerintah baik pemerintah pusat maupun pemerintah daerah untuk memenuhi hak dan kepentingan masyarakat. Dalam memenuhi kepentingan masyarakat tersebut penyelenggaraan pelayanan publik harus memiliki pelayanan yang berkualitas agar menghasilkan pelayanan yang efektif dan efisien. Kebijakan pelayanan publik tertuang pada undang-undang nomor 25 tahun 2009 yakni pelayanan publik merupakan kegiatan atau rangkaian kegiatan dalam rangka pemenuhan kebutuhan pelayanan sesuai dengan peraturan perundang-undangan bagi setiap warga negara dan penduduk atas barang, jasa, dan/atau pelayanan administratif yang disediakan oleh penyelenggara pelayanan publik yang dilaksanakan oleh institusi penyelenggara negara, korporasi, lembaga independen yang dibentuk berdasarkan undang-undang untuk kegiatan pelayanan publik.

Dengan adanya perkembangan zaman pelayanan publik dituntut untuk menyesuaikan pelayanan sesuai dengan semakin banyak dan kompleksnya kepentingan masyarakat. Dengan perkembangan zaman dan teknologi yang semakin maju pemerintah harus mampu membentuk pelayanan publik yang sesuai dengan perkembangan teknologi yang semakin berkembang. Untuk mengikuti teknologi yang semakin berkembang pemerintah pusat dan daerah menciptakan inovasi pelayanan publik berbasis teknologi informasi yang dapat memberikan pelayanan yang berkualitas dan dapat menyelenggarakan pelayanan publik yang semakin efektif dan efisien. Dengan adanya penyelenggaraan pelayanan publik berbasis teknologi informasi diharapkan kepentingan masyarakat dapat dengan mudah dilaksanakan oleh pemerintah dan masyarakat dapat memenuhi hak dan kepentingannya dengan mudah dan cepat. Pelayanan tersebut dinamakan e-government, menurut (World Bank, 2001) e-government dapat diartikan sebagai pemanfaatan teknologi informasi (seperti internet, telepon, satelit) oleh institusi pemerintahan untuk meningkatkan kinerja pemerintah dalam hubungannya dengan masyarakat, komunitas bisnis, dan kelompok terkait lainnya. Serta menurut Rogers WO Okut-Uma and Larry Caffrey (Eds), dalam buku Trusted Services and Public Key Infrastructure, Commonwealth Secretariat, 
London (2000), "E-government refers to the processes and structures pertinent to the electronic delivery of government services to the public."

Menurut Inpres Nomor 3 tahun 2003 mengenai penyelenggaraan pemerintahan berbasis teknologi informasi yang ditujukan ke pemerintah kota dan daerah. Dalam hal ini pemerintahan daerah harus melakukan pengembangan penyelenggaraan pemerintahan berbasis teknologi informasi. Hal itu pada saat ini sudah dilaksanakan oleh pemerintahan daerah Surakarta Jawa Tengah, dapat dilihat dari website domain pemerintahan Surakarta yakni surakarta.go.id yang dimana dalam website domain tersebut terdapat beberapa pelayanan yang dapat diakses dengan mudah oleh masyarakat di daerah Surakarta tersebut.

Karya tulis ilmiah ini ditujukan untuk mengetahui apa-apa saja pelayanan yang diselenggarakan dan terdapat di website domain pemerintahan kota Surakarta. Dan untuk mengetahui apakah website domain yang dikelola oleh pemerintahan kota Surakarta berjalan dengan baik atau tidak.

\section{KAJIAN TEORITIS}

\section{Pelayanan Publik}

Pelayanan publik dapat diartikan sebagai pemberian layanan keperluan orang atau masyarakat yang mempunyai kepentingan pada organisasi itu sesuai dengan aturan pokok dan tata cara yang telah ditetapkan. Dalam konteks pelayanan publik menurut Moenir (Kurniawan 2005 : 7) adalah kegiatan yang dilakukan oleh seseorang atau sekelompok orang dengan landasan faktor material melalui sistem, prosedur dan metode tertentu dalam usaha memenuhi kepentingan oranglain sesuai dengan haknya. Pemberian pelayanan publik oleh aperatur pemerintah kepada masyarakat sebenarnya merupakan implikasi dari fungsi aparat negara sebagai sebagai pelayan masyarakat.

Sedangkan menurut Departemen Dalam Negeri (Pengembangan Pelayanan Terpadu Satu Pintu, 2004) bahwa pelayanan publik adalah pelayanan umum, dan definisi pelayanan umum adalah satu proses bantuan kepada orang lain dengan caracara tertentu yang memerlukan kepekaan dan hubungan interpersonal tercipta kepuasan barang dan jasa. Dari uraian di atas pelayanan publik dapat diartikan 
sebagai aktivitas pemberian jasa baik oleh pemerintah maupun pihak swasta dengan cara-cara tertentu yang memerlukan kepekaan dan interpersonal dengan begitu tercipta suatu kepuasan barang dan jasa.

Menurut UU nomor 25 tahun 2009 tentang pelayanan publik adalah kegiatan atau rangkaian kegiatan dalam rangka pemenuhan kebutuhan pelayanan sesuai dengan peraturan perundang-undangan bagi setiap warga negara dan penduduk atas barang, jasa, dan/atau pelayanan administratif yang disediakan oleh penyelenggara pelayanan publik.

Berbagai definisi dan pemahaman tentang pelayanan publik tersebut pada intinya memiliki arah pandangan atau fokus yang hampir sama yakni pada pemberian pelayanan oleh instansi Pemerintah sebagai penyelenggara pelayanan publik kepada masyarakat, yang memiliki kepentingan terhadap institusi tersebut sesuai dengan aturan pokok dan tatacara yang telah ditetapkan. Saat ini yang menjadi permasalahan utama adalah bagaimana mewujudkan perbaikan penyelenggaraan pelayanan publik guna memenuhi tuntutan kebutuhan masyarakat dan perkembangan kondisi yang ada.

Menurut penjelasan di atas dapat dinyatakan bahwa pelayanan publik merupakan kegiatan untuk memenuhi segala kebutuhan dan kepentingan masyarakat sebagai pengguna pelayanan yang diberikan oleh penyelenggara pelayanan. Pemerintah Kota Surakarta sebagai penyelenggara pelayanan harus dapat menyelenggarakan pelayanan publik yang baik sesuai dengan Undang-undang yang berlaku.

\section{E-Government}

Menurut Bank Dunia (Samodra Wibawa 2009:113), E-Government adalah penggunaan teknologi informasi oleh instansi pemerintah seperti Wide Area Networks (WAN) internet, mobile competing, yang dapat digunakan untuk membangun hubungan dengan masyarakat, dunia usaha dan instansi pemerintah lainnya.

Menurut The World Bank Group (Fatih Suaedi, Bintoro Wardianto, 2010:54), egovernment ialah sebagai upaya pemanfaatan informasi dan teknologi komunikasi 
untuk meningkatkan efisiensi dan efektifitas, transparansi dan akuntabilitas pemerintah dalam memberikan pelayanan publik secara lebih baik.

Menurut Clay G. Weslatt (15 Agustus 2007) dalam website, e-government adalah menggunakan teknologi informasi dan komunikasi untuk mempromosikan pemerintah yang lebih efisien dan penekanan biaya yang efektif, kemudian fasilitas layanan terhadap masyarakat umum dan membuat pemerintah lebih bertanggung jawab kepada masyarakat.

Sedangkan dalam buku E-Government in Action (2005:5) menguraikan EGovernment adalah suatu usaha menciptakan suasana penyelenggaraan pemerintah yang sesuai dengan objektif bersama (shared goals) dari sejumlah komunitas yang berkepentingan, oleh karena itu visi yang dicanangkan juga harus mencerminkan visi bersama dari pada stakeholders yang ada misalnya, 1) memperbaiki produktifitas dan kinerja operasional pemerintah dalam melayani masyarakatnya. 2) mempromosikan pemerintah yang bersih dan transparan. 3) meningkatkan kualitas kehidupan masyarakat melalui kinerja pelayanan publik. 4) menjamin terciptanya penyelenggaraan yang demokratis.

Berdasarkan pengertian di atas dapat disimpulkan bahwa e-government merupakan bentuk penyelenggaraan pemerintahan berbasis teknologi informasi yang bertujuan untuk menciptakan pemerintahan yang lebih efektif dan efisien.

\section{Implementasi}

Impelementasi menurut Van Meter dan Abdul Wahab (2001:65) adalah suatu proses implementasi sangat dipengaruhi oleh sifat kebijakan yang akan dilaksanakan. Perubahan, kontrol dan kepatuhan bertindak merupakan konsep-konsep penting dalam prosedur implementasi. Sedangkan menurut Mazmanian dan Sabatier (dalam Widodo 2009:88) memaparkan bahwa implementasi adalah pelaksanaan keputusan dasar, biasanya dalam bentuk undang-undang, namun dapat pula berbentuk perintahperintah atau keputusan-keputusan eksekutif yang penting atau keputusan badan peradilan. Sedangkan menurut Ripley dan Franklin (dalam Winarno, 2012:148) berpendapat bahwa implementasi adalah apa yang terjadi setelah undang-undang 
ditetapkan yang memberikan otoritas program, kebijakan, keuntungan, atau suatu jenis keluaran yang nyata.

\section{PEMBAHASAN}

\section{Pelaksanaan E-Government di Kota Surakarta}

Kebutuhan masyarakat akan pelayanan yang efektif dan efisien pada saat ini mendorong pemerintah untuk dapat menyelenggarakan pelayanan yang efektif dan efisien guna mencapai kepentingan masyarakat. Terlebih dengan adanya perkembangan zaman dan kemajuan teknologi serta kompleksnya kepentingan masyarakat mengakibatkan pemerintah harus mewujudkan pelayanan yang prima guna mencapai tujuan pemerintahan yakni memenuhi kepentingan masyarakat yang dimana penyelenggaraan pelayanan tersebut harus mampu berdampingan dengan perkembangan zaman guna memenuhi kepentingan masyarakat.

Maka dari itu pemerintah harus dapat memberikan atau menyelenggarakan pelayanan yang prima dengan menggunakan teknologi informasi dalam penyediaan pelayanan kepada masyarakat. Hal itu tertuang dalam Instruksi Presiden nomor 3 tahun 2003 mengenai pelaksanaan atau penerapan pemerintahan dengan menggunakan atau menerapkan pelayanan berbasis teknologi informasi yang dimana ditujukan guna menciptakan pelayanan yang lebih efektif dan efisien bagi masyarakat sebagai pengguna layanan.

Dengan adanya Instruksi Presiden tersebut maka hampir setiap daerah di masingmasing Provinsi sudah menerapkan atau menyelenggarakan pelayanan yang berbasis pada teknologi informasi, salah satunya kota atau daerah Surakarta Jawa Tengah yang sudah menyelennggarakan pelayanan berbasis teknologi informasi melalui website domain Surakarta.go.id.

Dalam Surakarta.go.id terdapat banyak pilihan pelayanan yang disediakan oleh pemerintahan Kota Surakarta dan juga terdapat banyaknya pillihan informasi yang tersedia di dalam website domain pemerintahan Kota Surakarta tersebut. Layanan yang tersedia di website domain Surakarta.go.id meliputi pengaduan masyarakat, layanan perizinan layanan kependudukan, layanan kepegawaian, monitoring 
pembangunan, layanan pendidikan, lowongan pekerjaan informasi publik, layanan surat, pengadaan barang dan jasa, layanan kesehatan, pantauan lalu lintas, informasi DPRD, informasi hukum, dan uji kelaikan kendaraan.

Layanan pertama yang terdapat dalam website domain Surakarta.go.id yakni pengaduan masyarakat yang bernama ulas (unit layanan aduan Surakarta). Dalam layanan ini pemerintah Kota Surakarta memberikan wadah bagi masyarakat untuk menyampaikan aspirasinya ke pemerintahan mengenai berbagai aspek kehidupan. Dalam layanan ini juga tersedia dalam bentuk aplikasi yang dapat diunduh hanya melalui google play store. Untuk menyampaikan aspirasi ke ulas ini cukup mudah, masyarakat hanya mengisi nama, alamat e-mail, nomor handphone, kategori di bagian bidang apa yang menjadi topic aspirasi (misal bagian kependudukan atau perhubungan), judul aspirasi, dan isi dari keluhan atau aspirasi yang ingin disampaikan. Setelah itu nantinya keluhan masyarakat akan segera direspon oleh kategori atau departemen yang terkait dalam aspirasi masyarakat tersebut.

Layanan kedua yakni perizinan online, di dalam perizinan online terdapat beberapa pilihan seperti daftarkan perizinan, informasi perizinan, informasi progress, dan hubungi kami. Di dalam pilihan daftarkan perizinan masyarakat harus masuk menggunakan username dan password yang sebelumnya sudah melakukan pembuatan akun untuk melakukan pendaftaran perizinan. Pilihan informasi perizinan berisikan informasi-informasi perizinan apa yang tersedia dan apa-apa saja persyaratan yang dibutuhkan untuk mendaftarkan perizinan tersebut. Selanjutnya pilihan informasi progress yang mana dalam pilihan ini untuk memberikann informasi kepada masyarakat untuk mengetahui sudah sampai mana proses perizinan masyarakat itu. Dan yang terakhir yakni hubungi kami, pilihan ini berisikan kontak yang dapat dihubungi untuk mendaftarkan perizinan.

Layanan ketiga yakni layanan pendidikan, dalam layanan pendidikan ini hanya terdapat berita-berita atau event-event yang berkaitan dengan pendidikan seperti pedoman pemilihan guru berprestasi, pedoman pemilihan kepala sekolah berprestasi, dan penawaran diklat untuk para guru. Serta dalam layanan ini juga terdapat penyebaran institusi pendidikan di setiap kecamatan. 
Layanan selanjutnya yakni lowongan kerja, dalam layanan ini berintegritas dan bersinergi dengan departemen tenaga kerja Surakarta, yang mana lowongan pekerjaan yang dibutuhkan masyarakat dapat diperoleh informasinya dengan mudah.

Dan layanan selanjutnya yakni layanan kesehatan, di dalam layanan kesehatan hanya tersedia jumlah tempat tidur rawat inap yang tersedia di rumah sakit Kota Surakarta, lokasi rumah sakit di Kota Surakarta, jalur ambulans, dan stok darah yang tersedia di PMI Kota Surakarta. Dalam layanan ini belum tersedianya layanan antre online yang sebagaimana sudah diterapkan pada salah satu daerah di Indonesia.

Ada juga layanan kependudukan yang mengusung konsep smart city yakni”solo smart city" e-kelurahan. Namun penulis tidak dapat mengakses sebab untuk mengakses layanan ini harus mendaftarkan atau membuat akun di Kelurahan masingmasing.

Dari kesemua layanan yang tersedia di website domain Kota Surakarta semuanya sudah terintegrasi dengan departemen-departemen Kota Surakarta. Selain itu juga di dalam website domain pemerintahan Kota Surakarta berita-berita dan informasiinformasi yang diberikan merupakan berita-berita yang terbaru dan senantiasa up to date.

\section{SIMPULAN}

Pelaksanaan pemerintahan berbasis teknologi informasi di Kota Surakarta melalui website domain Surakarta.go.id sudah dilaksanakan dengan sangat baik. Hal itu dapat dilihat dari jenis-jenis layanan yang disediakan dan aktivitas-aktivitas yang berjalan di dalam website domain tersebut. Layanan-layanan yang disediakan cukup banyak dan dapat dengan mudah diakses oleh masyarakat, adanya respon dari departemen Kota Surakarta dalam menanggapi segala bentuk aspirasi dari masyarakat yang terbilang cukup cepat serta berita-berita dan informasi yang diberikan kepada masyarakat merupakan informasi yang up to date.

Namun terdapat juga layanan yang cenderung sederhana, seperti layanan kesehatan yang hanya terdapat informasi mengenai ketersediaan tempat tidur rawat 
inap di setiap rumah sakit di Kota Surakarta dan informasi mengenai jumlah darah yang tersedia di Palang Merah Kota Surakarta, belum adanya antrean untuk menggunakan layanan kesehatan mengakibatkan layanan ini belum maksimal.

Jadi dapat disimpulkan bahwa pelaksanaan pemerintahan di Kota Surakarta dapat diartikan sudah cukup baik dan sudah menjalankan apa yang sudah diinstruksikan oleh Presiden dalam Instruksi Presiden nomor 3 tahun 2003.

\section{DAFTAR PUSTAKA}

Habsari, Rizki Dwi. 2016. "Implementasi Peraturan Daerah Nomor 2 Tahun 2011 tentang Pengelolaan sampah di Kelurahan Karang Anyar Kecamatan Sungai Kunjang Kota Samarinda". Ejournal Ilmu Pemerintahan, Vol. 4, No. 1, hlm. 282-293.

Indrajit, Richardus Eko. 2006. E-Government in Action. Yogyakarta: Andi Publisher.

Instruksi Presiden Republik Indonesia nomor 3 tahun 2003 tentang Kebijakan dan Strategi Nasional Pengembanan E-Government.

Moenir. 2008. Manajemen Pelayanan Umum di Indonesia. Jakarta: PT. Bumi Aksara.

Suaedi, Falih., Wardiyanto, Bintoro. 2010. Revitalisasi Administrasi Negara (Reformasi Birokrasi dan E-Government). Yogyakarta: Graha Ilmu.

Undang-Undang nomor 25 tahun 2009 tentang Pelayanan Publik.

Yin RK. 2004. Studi Kasus Desain dan Metode, Jakarta. PT Raja Grafindo Persada. 